\title{
Developing a Sweet Corn Simulation Model to Predict Fresh Market Yield and Quality of Ears
}

\author{
J.I. Lizaso ${ }^{1}$, K.J. Boote, C.M. Cherr, and J.M.S. Scholberg \\ Agronomy Department, University of Florida, P.O. Box 110500, Gainesville, FL 32611-0500
}

J.J. Casanova and J. Judge

Center of Remote Sensing, Agricultural and Biological Engineering Department, University

of Florida, Gainesville, FL 32611-0570

J.W. Jones
Agricultural and Biological Engineering Department, University of Florida, Gainesville,
FL 32611-0570

G. Hoogenboom

Department of Biological and Agricultural Engineering, University of Georgia, Griffin, GA 30223-1731

\begin{abstract}
AdDitional INDEX words. ear fresh mass, CSM-CERES-Maize, DSSAT, Zea mays
Abstract. Current production of sweet corn (Zea mays L.) in the United States is 4.0 million Mg with a value of \$807 million. The fresh market component amounts to three-fourths of this value with California, Florida, and Georgia harvesting half of the U.S. fresh market production. Existing maize simulation models have limited potential to assist sweet corn production as a result of the distinctive nature of the marketed end product (i.e., fresh market ears versus dry mature kernels). The purpose of this study was to develop a sweet corn simulation model. The Cropping System Model-Crop-Environment Resource Synthesis CSM-CERES-Maize simulation model, version 4.0, was modified to improve the simulation of ear growth, to predict ear fresh market yield, and to predict fresh market ear quality according to U.S. standards. A field experiment conducted in Florida in 2003 was used for model development. Five nitrogen fertilization levels $\left(0,67,133,200\right.$, and $\left.267 \mathrm{~kg} \cdot \mathrm{ha}^{-1} \mathrm{~N}\right)$ were applied to a sh2-based commercial hybrid with a Bt gene sown at 8.2 plants $/ \mathrm{m}^{2}$. Three additional experiments conducted in 2002, 2004, and 2005 provided independent data to evaluate the new model. In 2002, the treatments and hybrid were the same as mentioned, but the population density was 5.5 plants $/ \mathrm{m}^{2}$. A yellow $s h 2$-based hybrid with a Bt gene was planted at 6.1 plants $/ \mathrm{m}^{2}$ in 2004 . In 2005, a bicolor sh2-based hybrid with a Bt gene was planted at 8.1 plants $/ \mathrm{m}^{2}$. The 2004 and 2005 experiments had $100 \%$ and $150 \%$ of the Florida $N$ recommendations applied to the crop. Results indicated that the new model was able to simulate adequately crop and ear growth of sweet corn. The ear dry weight simulation was improved as indicated by $30 \%$ reduction of root mean square of the error (RMSE) when the new model was compared with the original CSMCERES-Maize. Total ear fresh weight yield and marketable yield were also simulated reasonably well with RMSE values of 3367 and $3502 \mathrm{~kg} \cdot \mathrm{ha}^{-1}$, respectively. The simulation of ear quality was consistently overpredicted at intermediate levels of $\mathbf{N}$ fertilization, indicating the need to further examine the impact of limited $\mathbf{N}$ on ear quality.
\end{abstract}

Sweet corn is one of the most important vegetable crops in the United States. During the last 2 years $(2004,2005)$, the United States produced $\approx 4.0$ million $\mathrm{Mg}$ of sweet corn with a value of $\$ 807$ million. This production targeted three distinct markets: fresh, canning, and freezing. The fresh market component accounted for $31 \%$ of the production and more than $73 \%$ of the production value [U.S. Dept. of Agriculture (USDA), 2005].

Sweet corn is grown in every state in the United States. However, the attraction of premium prices for fresh market sweet corn has promoted the production of this vegetable in southern states, where warmer soil and air temperatures allow earlier sowing and longer growing season. California, Florida,

Received for publication 2 Nov. 2006. Accepted for publication 13 Mar. 2007. The MicroWEXs were funded by the NASA-New Investigator Program, Grant Number 0005065, the NSF-Earth Science Directorate, EAR-0337277, and UF/IFAS.

${ }^{1}$ Corresponding author. E-mail: jlizaso@uff.edu. and Georgia together account for more than $50 \%$ of the fresh market production of sweet corn (USDA, 2005).

Sweet corn differs from field corn as a result of mutant genes affecting the endosperm. The mutations alter the starch synthesis pathway resulting in kernels with endosperm higher in sugar or phytoglycogen and lower in starch (Tracy, 2001). Reduced starch content is one of the reasons for decreased germination, emergence, seedling vigor, and uneven stands in commercial sweet corn as compared with field corn.

Fresh market production of sweet corn is strongly seasonal in the United States. The volume peaks in July with only $10 \%$ of the annual volume being marketed in winter mostly coming from Florida (USDA, 2005). Fresh sweet corn is also perishable as a result of rapid decrease of sugar content, kernel desiccation, husk discoloration, and risk of pathogen infestation (Rodov et al., 2000). Together, the high value of this fresh market vegetable, the pronounced seasonal production, and its perishable nature intensify interest in predicting accurately timing and fresh weight production of the crop. A sweet corn 
simulation model could assist crop production planning by exploring alternative planting dates matching crop requirements with local soil and weather patterns. Fine-tuning production for optimum harvest timing can result in better prices. Such a simulation model could also be used to optimize crop management examining changes to practices such as population densities, irrigation, and fertilization.

Despite improvements in maize simulation models since the early efforts of the 1970s and 1980s (Duncan, 1975; Jones and Kiniry, 1986; Stapper and Arkin, 1980), no attempt has been made to develop a sweet corn simulation model. Because the marketed end product is different between field corn (dry mature kernels) and sweet corn (fresh market ears), simulation models developed for field maize have limited potential for assisting decision-makers in sweet corn production.

In the present work, we developed a sweet corn simulation model by modifying CSM-CERES-Maize (Jones et al., 2003). We focused on improving the simulation of ear growth and added a new module to simulate ear fresh market yield components. Additionally, we implemented and tested a method to estimate ear quality using the USDA standards for fresh market sweet corn (USDA, 1992).

\section{Materials and Methods}

\section{Model development}

The CSM-CERES-Maize model (Jones et al., 2003), the maize simulation model distributed with DSSAT 4.0 (Hoogenboom et al., 2004), was modified to simulate growth and yield of sweet corn crops. The default soil-organic matter $\mathrm{N}$ model (Godwin and Singh, 1998) was used. For simplicity, the modified model will be referred to as CERES-Sweet Corn and the original model as CERES-Maize.

Model Development data. We used data collected in a field experiment in Florida in 2003 (Cherr et al., 2006) to develop CERES-Sweet Corn. Sweet corn hybrid 'GSS 0966' was sown on 7 Apr. 2003 in an arenic paleudult soil (lat. 29.4, long. -82.2, $21 \mathrm{~m}$ elevation) in 10-row plots that were $15 \mathrm{~m}$ long with a row spacing of $0.76 \mathrm{~m}$ and a population density of $8.2 \mathrm{plants} / \mathrm{m}^{2}$. 'GSS 0966' is a yellow hybrid with shrunken (sh2) and Bt genes commercialized by Syngenta (Syngenta Seeds, Boise, Idaho). Nitrogen fertilizer was applied at doses of $0,67,133,200$, and $267 \mathrm{~kg} \cdot \mathrm{ha}^{-1} \mathrm{~N}$. Fertilization was split into three equal applications: at emergence and 3 and 5 weeks after emergence. Ears were harvested manually in the middle $4.6 \mathrm{~m}$ of six consecutive rows $\left(20.85 \mathrm{~m}^{2} / \mathrm{plot}\right)$ and fresh weights were obtained. Ears were graded according to the USDA standards for fresh market (USDA, 1992) using representative samples of each plot. Additional experimental details are provided by Cherr et al. (2006).

Changes to the source code of the model focused on three components: 1) ear growth, 2) ear fresh weight, and 3) ear quality.

Ear dRy MatTer accumulation. In the current CERESMaize model, ear dry weight is initialized at flowering as $16.7 \%$ of the stem dry weight. Otegui and Bonhomme (1998) reported that ear elongation (expansive growth) starts at 227 growing degree days (GDD) before silking and ends at 100 GDD after silking. In CERES-Sweet Corn, the ear grows (i.e., accumulates dry weight) during a thermal time window from $250 \mathrm{GDD}$ before silking through $170 \mathrm{GDD}$ after silking, when the linear grain filling begins. After the start of the linear grain filling, only the seeds grow. The ear sink strength for assimilates is simulated following a sigmoidal relationship of thermal time:

$$
\text { Pear }=\frac{0.81}{1+e^{-0.02(\text { TTear }-210)}}
$$

where Pear is the fraction of daily assimilates partitioned into the ear and TTear is the cumulative thermal time since the onset of ear growth (Fig. 1). The shape of Eq. 1 was chosen to represent the biologic process of ear growth (Otegui and Bonhomme, 1998). The parameters were empirically fitted to simulate correctly ear growth of our model development data set. By the time of silking, Eq. 1 allocates $56 \%$ of the daily assimilates to the ear and $80 \%$ at the onset of linear grain filling. Ear growth rate [GRear (grams per day)] is calculated as:

$$
\text { GRear }=\text { Pear } \times \text { GR plant }
$$

where GRplant $\left(\mathrm{g} \cdot \mathrm{d}^{-1}\right)$ is the plant growth rate. Dry weight of ears [DWear (grams per plant)] is updated daily by adding GRear.

CERES-Maize computes ear mass as part of the stem mass before silking. Thus, in CERES-Sweet Corn, the ear growth rate is subtracted from the stem growth rate before silking. During this time also, minimum root growth demand is assumed to be $10 \%$ of the daily assimilates (Jones and Kiniry, 1986). Thus, leaf, stem, and ear growth rates are reduced proportionally as required to meet this minimal root demand.

EAR FRESH WEIGHT. Ear dry weight concentration increases slowly with ear growth (Fig. 2). The model simulates the increase in ear dry weight concentration $(D M C)$, expressed as a fraction of ear fresh weight, with a slope of 0.0002 per unit of thermal time (Fig. 2). The function was derived from the 2003 field experiment. Fresh weight of ears [FWear (grams per plant)] is calculated as:

$$
F W e a r=\frac{D W e a r}{D M C}
$$

where DWear is the ear dry weight (grams per plant). Using the plant population density and FWear, the model calculates total fresh weight yield of ears [TotFW (kilograms per hectare)].

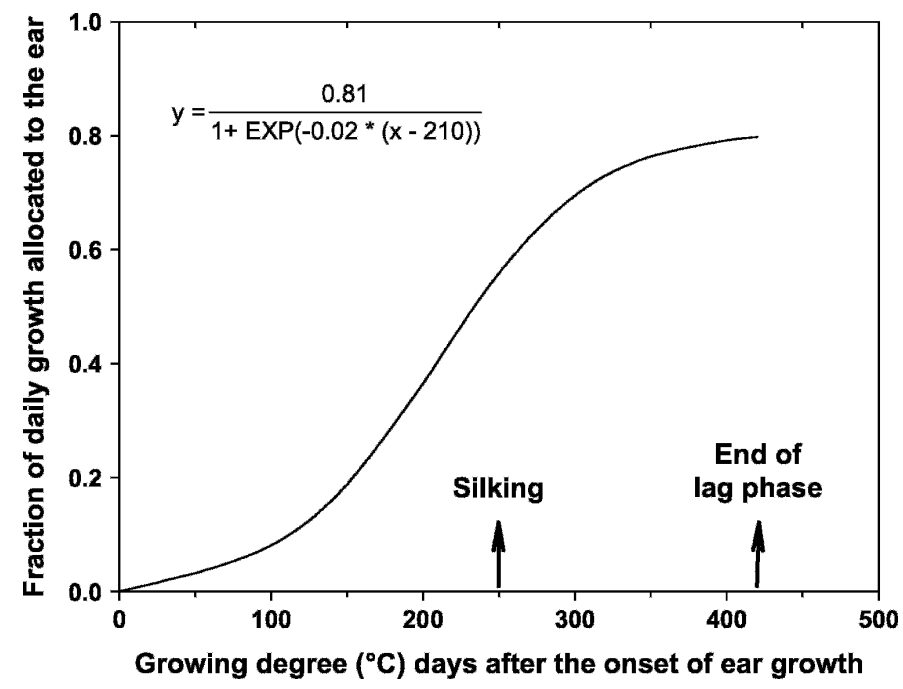

Fig. 1. Thermal time progression of simulated fraction of daily growth rate partitioned into the ear of sweet corn as implemented in CERES-Sweet Corn. The time scale is growing degree days calculated with a base temperature of $8{ }^{\circ} \mathrm{C}$. 


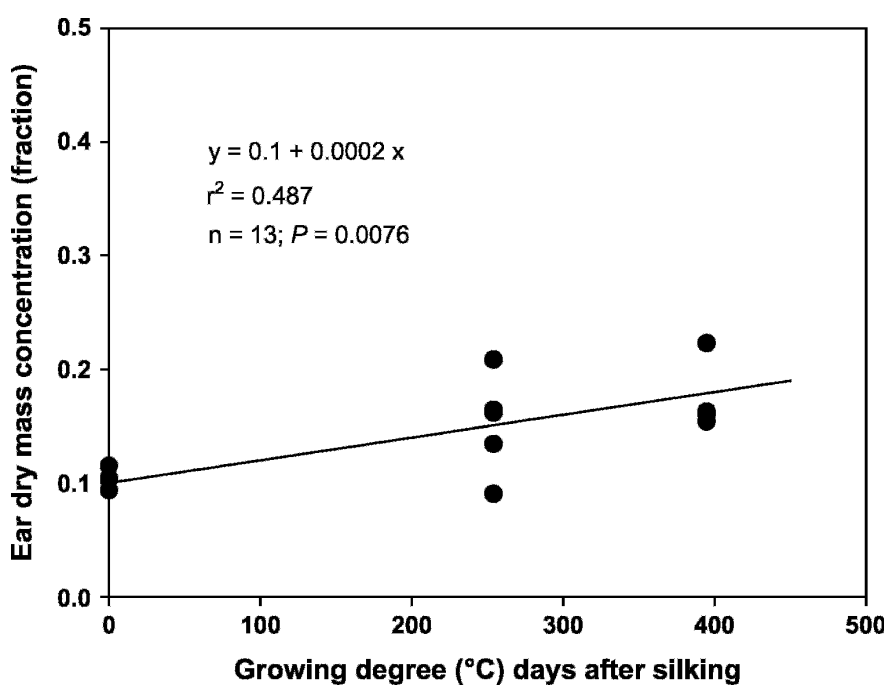

Fig. 2. Thermal time progression of ear dry weight concentration of sweet corn used to calculate ear fresh weight in CERES-Sweet Corn. The time scale is growing degree days calculated with a base temperature of $8^{\circ} \mathrm{C}$.

EAR Quality. We implemented in CERES-Sweet Corn the simulation of the U.S. standards for fresh market of sweet corn ears (USDA, 1992). The classification system separates three main classes based on ear condition and length of cob covered with grains: "Fancy" (not less than $15.2 \mathrm{~cm}$ ), "US No. 1" (not less than $12.7 \mathrm{~cm}$ ), and "US No. 2" (not less than $10.2 \mathrm{~cm}$ ). Ears that exhibit poor quality such as those affected by damage, discoloration, poor grain filling, or small size (i.e., less than $10.2 \mathrm{~cm}$ ) are considered nonmarketable. Ear fresh weight and size were too variable in the classes US No. 1 and US No. 2 in our model development data set. Therefore, CERES-Sweet Corn only separates Fancy ear fresh weight and number, calculating aggregate values for US No. 1 and US No. 2 ears.

Our model development data set indicated that marketable fresh weight yield is a predictable function of the total fresh weight of ears produced (Fig. 3). Under stress conditions such as those created by limited levels of available water, nitrogen, or other nonspecified limiting growing condition, the

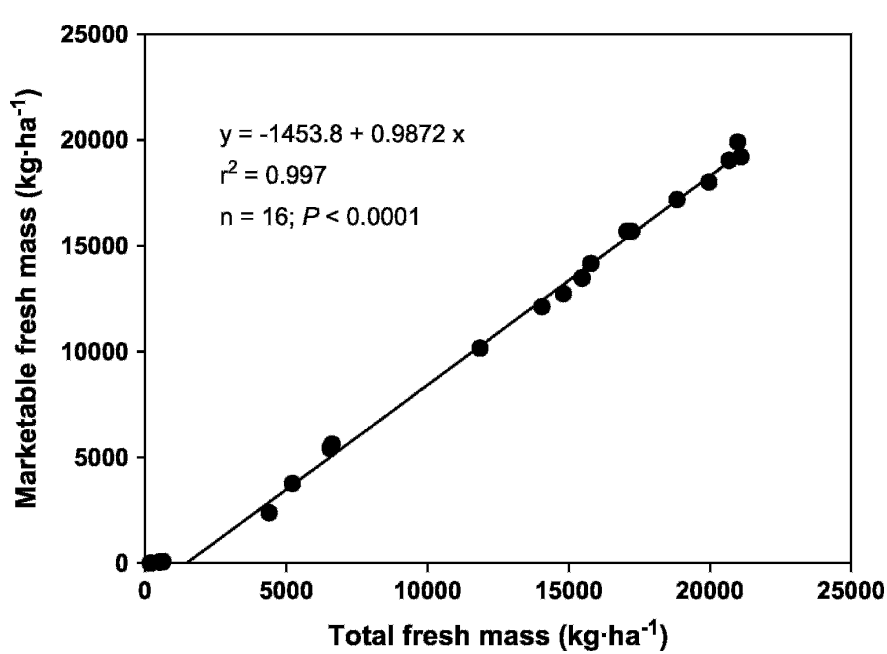

Fig. 3. Relationship between marketable ear fresh weight yield and total ear fresh weight yield of sweet corn as implemented in CERES-Sweet Corn. Data points with total fresh weight less than $1000 \mathrm{~kg} \cdot \mathrm{ha}^{-1}$ were not included in the analysis. proportion of marketable ears is expected to decrease. Therefore, marketable ear fresh weight $[M k t F W$ (kilograms per hectare)] is calculated as:

$$
\begin{aligned}
M k t F W= & (0.987 \text { TotFW }-1453.8) \times S L P F \times \\
& A M I N 1(W S F, N S F)
\end{aligned}
$$

where Tot $F W$ is the total ear fresh weight yield (kilograms per hectare) and SLPF is a zero to one input in the soil file used to reduce simulated crop growth associated with poor soil fertility conditions other than nitrogen. $A M I N 1$ is a Fortran function that selects the most limiting (i.e., minimum) stress factor resulting from water $(W S F)$ or nitrogen $(N S F)$.

Marketable fresh weight is split into Fancy fresh weight and US No. 1 plus US No. 2 fresh weight (USDA, 1992). The model calculates the fraction of Fancy fresh weight corresponding to the calculated value of marketable fresh weight (Fig. 4). Highquality Fancy ears have a rather consistent average mass per ear. Data depicted in Figure 5A indicates that Fancy ear numbers can be estimated assuming an average of $247 \mathrm{~g} / \mathrm{ear}$ $(1 / 4.05=0.247)$.

US No. 1 plus US No. 2 fresh weight yield is calculated by subtracting the Fancy fresh weight from the marketable fresh weight. Using the relationship shown in Figure 5B, fresh weight yield of US No. 1 plus US No. 2 is used to compute the corresponding ear numbers.

New outPut FILE. CERES-Sweet Corn outputs a new file, FreshWt.out, summarizing the ear fresh weight simulation variables. The file features the same standard heading of other DSSAT output files. Beginning at flower initiation (ISTAGE = 3) through harvest, it provides daily values of ear dry weight concentration (fraction), ear fresh weight (grams per plant), ear dry weight (grams per plant), and the fresh weight (kilograms per hectare) of total ear yield, marketable ear yield, Fancy ear yield, and US No. 1 + US No. 2 ear yield. The output file also includes ear numbers (ears/ha) of Fancy and US No. 1 + US No. 2 ears.

\section{Model evaluation}

Evaluation Data. To evaluate CERES-Sweet Corn, we used 3 years of field data collected at the University of Florida

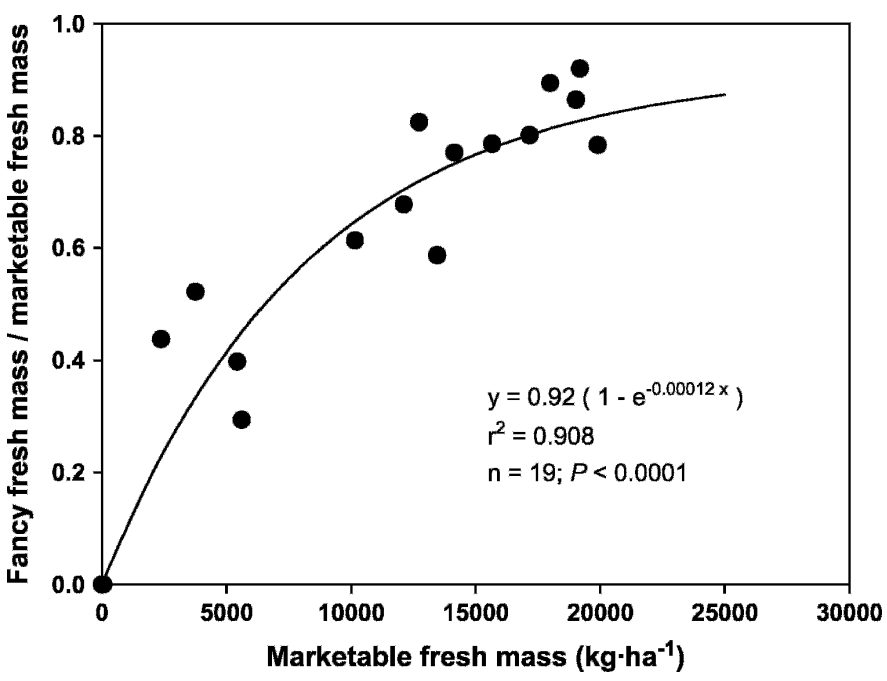

Fig. 4. Relationship between the ratio of Fancy ear fresh weight to total marketable fresh weight, and the marketable fresh weight yield per unit land area of sweet corn as implemented in CERES-Sweet Corn. 

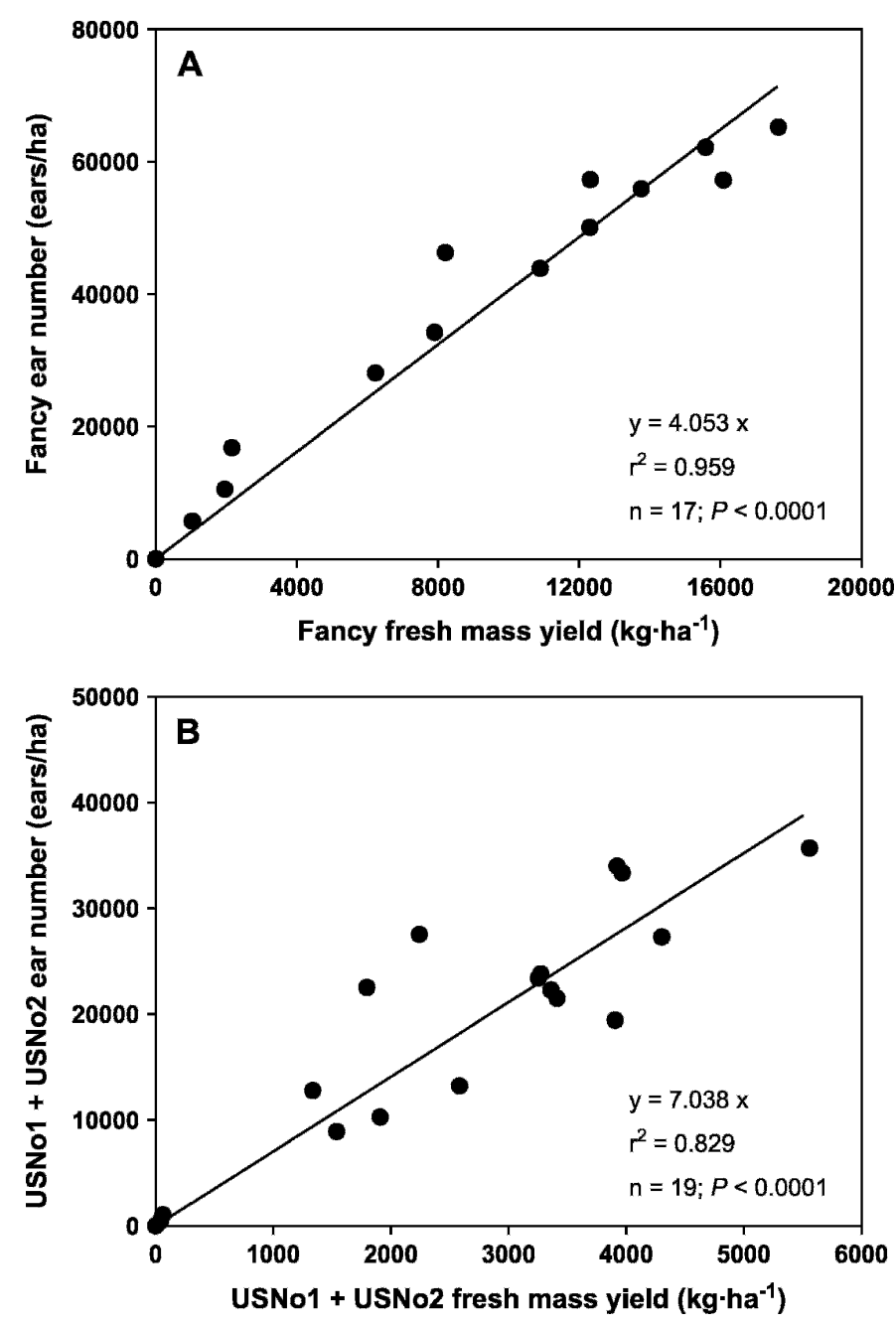

Fig. 5. Relationship between ear number and ear fresh weight yield of sweet corn for (A) Fancy ears and for (B) US No. $1+$ US No.2 ears as implemented in CERES-Sweet Corn.

Plant Science Research and Education Unit, near Citra, Fla. (lat. 29.4, long. $-82.2,21 \mathrm{~m}$ elevation). The first test data were collected in an experiment similar to the one reported in the model development section (Cherr et al., 2006). The same hybrid ('GSS 0966') was sown on 26 Apr. 2002 in an arenic paleudult soil with identical fertilization treatments. However, stand establishment was impaired and population density as evaluated at harvest was only $5.5 \mathrm{plants} / \mathrm{m}^{2}$. Data from two additional experiments, sown in a 3.6-ha field on a grossarenic paleudult soil, in 2004 and 2005 were also used. The hybrid 'Saturn' was sown on 18 Mar. 2004 at a population density of $6.1 \mathrm{plants} / \mathrm{m}^{2}$ (Judge et al., 2005). 'Saturn' is a yellow hybrid with sh2 and Bt genes commercialized by Seedway (Seedway, LLC, Hall, N.Y.). Irrigation was supplied by a linear move system that also provided a method for applying $\mathrm{N}$ fertilization (fertigation). One half of the field received $100 \%$ of the Floridarecommended $\mathrm{N}$ fertilization $\left(252 \mathrm{~kg} \cdot \mathrm{ha}^{-1} \mathrm{~N}\right)$ split in 11 applications and the other half received $\approx 150 \%$ of Florida recommendation $\left(419 \mathrm{~kg} \cdot \mathrm{ha}^{-1} \mathrm{~N}\right)$ split in eight applications. The hybrid 'BSS 0977' was sown on 11 Mar. 2005 at a population density of 8.1 plants $/ \mathrm{m}^{2}$ (Casanova et al., 2005). 'BSS 0977' is a bicolor hybrid with sh2 and Bt genes commercialized by Syngenta. The two N rates were 292 and $379 \mathrm{~kg} \cdot \mathrm{ha}^{-1} \mathrm{~N}$ ( $\approx 100 \%$ and $150 \%$ of Florida recommendations).

Daily weather data were obtained from the Florida Automated Weather Network (University of Florida, 2006) for the Citra location. A typical Millhopper fine sand (arenic paleudult) soil was considered representative of the experimental site. Genetic coefficients were calibrated so that the model simulations of phenology and shoot biomass were close to measured values (data not shown). Table 1 shows the calibrated genetic coefficients used in this study.

Two statistical indices were used to compare observed and model simulated values. The RMSE was calculated as:

$$
R M S E=\left[\frac{1}{n} \sum_{i=1}^{n}\left(S_{i}-O_{i}\right)^{2}\right]^{0.5}
$$

where $S_{i}$ and $O_{i}$ are a corresponding pair of simulated and measured values, respectively, and $n$ is the number of observations included in the evaluation. The parameter $\mathrm{d}$ or Willmott's index of agreement (Willmott, 1982) was calculated as:

$$
d=1-\left[\frac{\sum_{i=1}^{n}\left(S_{i}-O_{i}\right)^{2}}{\sum_{i=1}^{n}\left(\left|S_{i}^{\prime}\right|+\left|O_{i}^{\prime}\right|\right)^{2}}\right]
$$

where $S_{i}^{\prime}=S_{i}-\bar{O}$ and $O_{i}{ }^{\prime}=O_{i}-\bar{O}$. Parameter $d$ lies within the range 0 to1 with higher values indicating more accurate simulations.

Sensitivity analysis. We examined the stability of CERESSweet Corn by simulating conditions of limited water supply and $\mathrm{N}$ fertilizer and changing the thermal regime and the plant population density. We report model simulations of ear dry weight (grams per plant) and marketable yield (kilograms per hectare) at harvest. Limited water supply was simulated by

\begin{tabular}{|c|c|c|c|c|c|c|}
\hline Hybrid & $\mathrm{P} 1^{\mathrm{y}}$ (degree days) & $\mathrm{P} 2^{\mathrm{x}}\left(\mathrm{d} \cdot \mathrm{h}^{-1}\right)$ & P5w (degree days) & $\mathrm{G}^{\mathrm{v}}$ (kernel/plant) & $\mathrm{G}^{\mathrm{u}}\left(\mathrm{mg} \cdot \mathrm{d}^{-1}\right)$ & PHINT $^{t}$ (degree days) \\
\hline GSS 0966 & 150.0 & 0.3 & 680.0 & 600.0 & 5.5 & 43.0 \\
\hline Saturn & 180.0 & 0.3 & 738.0 & 850.0 & 15.0 & 35.0 \\
\hline BSS 0977 & 155.0 & 0.3 & 738.0 & 600.0 & 5.0 & 48.0 \\
\hline
\end{tabular}

Table 1. Genetic coefficients of the sweet corn hybrids used in this study. ${ }^{\mathrm{z}}$

${ }^{\mathrm{z}}$ Simulations were obtained with CERES-Sweet Corn.

${ }^{\text {y }} 1=$ Thermal time from emergence to the end of the juvenile phase (degree days calculated with a base temperature of $8{ }^{\circ} \mathrm{C}$ ).

${ }^{x} \mathrm{P} 2=$ Delay in completing flower induction (d) for each hour increase in photoperiod above which development proceeds at a maximum rate (12.5 h).

${ }^{\text {wP5 }}=$ Thermal time from silking to physiological maturity (degree days calculated with a base temperature of $8{ }^{\circ} \mathrm{C}$ ).

${ }^{\mathrm{v}} \mathrm{G} 2=$ Potential number of kernels per plant.

${ }^{\mathrm{u}} \mathrm{G} 3=$ Potential kernel growth rate during the linear grain filling stage.

${ }^{\mathrm{t}} \mathrm{PHINT}=$ Phyllochron, thermal time between the appearance of consecutive leaf tips (degree days calculated with a base temperature of $8{ }^{\circ} \mathrm{C}$ ). 
iteratively reducing the daily water inputs. Seasonal rainfall (in millimeters) was cumulative precipitation from 2 weeks before planting to harvest. Similarly, limited N fertilizer was simulated by gradually reducing the fertilizer application amounts. Changes in thermal regime were simulated by adding or subtracting 2.5 or $5.0^{\circ} \mathrm{C}$ to the daily maximum and minimum temperatures. Changes in population densities were simulated by modifying the original population of 8.2 plants $/ \mathrm{m}^{2}$ to examine the range from 2 to 20 plants $/ \mathrm{m}^{2}$.

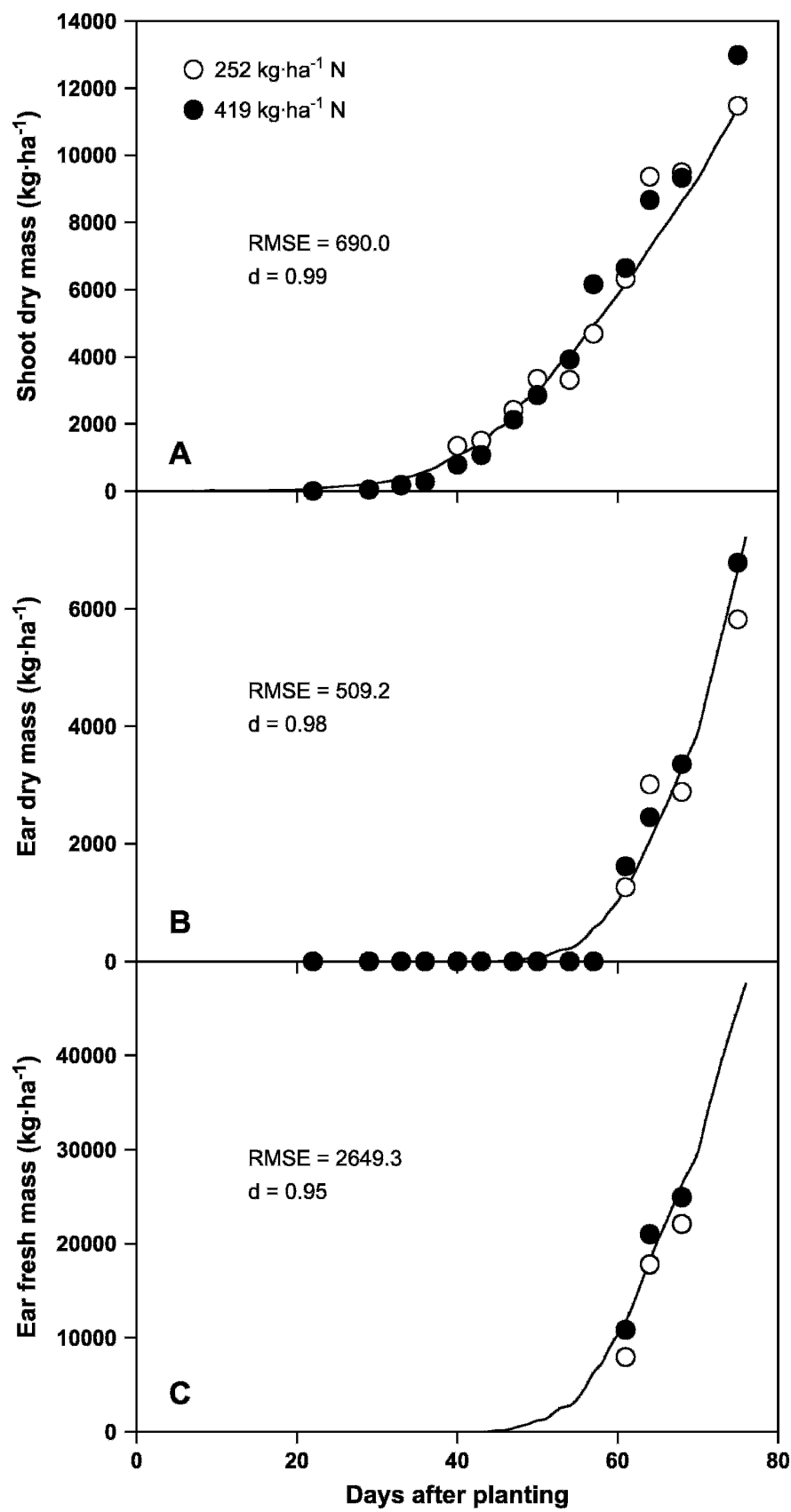

Fig. 6. Model-simulated and field-measured progression of seasonal growth of shoot and ear of sweet corn for 252 and $419 \mathrm{~kg} \cdot \mathrm{ha}^{-1} \mathrm{~N}$ treatments in 2004. Simulations were obtained with CERES-Sweet Corn: (A) shoot biomass ( $\mathrm{n}=$ 28, $P<0.0001)$; (B) ear dry weight ( $\mathrm{n}=8, P<0.0001)$; (C) ear fresh weight $(\mathrm{n}=6, P=0.007)$. RMSE $=$ root mean square of the error; $\mathrm{d}=$ Willmott's index of agreement.

\section{Results and Discussion}

CERES-Sweet Corn exhibited very good performance simulating the seasonal crop growth and ear yield of sweet corn crops. The seasonal progression of crop growth appears in Figure 6A. Similar to measured values, the model simulated no growth differences for $100 \%$ versus $150 \%$ of recommended $\mathrm{N}$ fertilization levels. The new functions used to calculate ear dry weight (Fig. 1) and ear fresh weight (Fig. 2) also produced excellent simulations (Fig. 6B, C).

EAR DRY WEIGHT SIMULATION. The first objective of this study was to improve the simulation of ear growth. Simulations of ear growth for three independent seasons (Fig. 7) indicated that the CERES-Maize model (old) has a general trend to underpredict, particularly at high levels of productivity (Fig. 7, open symbols, dotted line). However, when ear growth is simulated using the assimilate partitioning depicted in Figure 1, the (new) model accuracy improved by almost $30 \%$ as indicated by reduction in RMSE (498 vs. $701 \mathrm{~kg} \cdot \mathrm{ha}^{-1}$ ). Ear growth simulation improvements were also indicated by the regression slope (0.98 vs. $0.85)$ and Willmott's d index (0.98 vs. 0.95$)$.

EAR FRESH WEIGHT Simulation. The second objective of this work was to develop an ear fresh weight simulation component. Simulations of ear fresh market yields for three independent years appear on Figure 8. The model consistently overpredicted ear fresh weight across the range of values examined. However, the data presented in Figure 8 are likely biased because of factors influencing the 2005 data. During the growing season of 2005 , there was a succession of events that delayed and reduced crop growth. On 28 Mar., 16 d after planting (DAP), crop lodging was observed in the experimental field associated with strong winds. Additional crop lodging occurred $10 \mathrm{~d}$ later on 7 Apr. (26 DAP) when rain fell at an average intensity of 99 $\mathrm{mm} \cdot \mathrm{h}^{-1}$ accompanied by wind speed of $29 \mathrm{~km} \cdot \mathrm{h}^{-1}$ over a $15-\mathrm{min}$ period. The effects of strong winds and short-term, highintensity rain on crop performance are not simulated currently

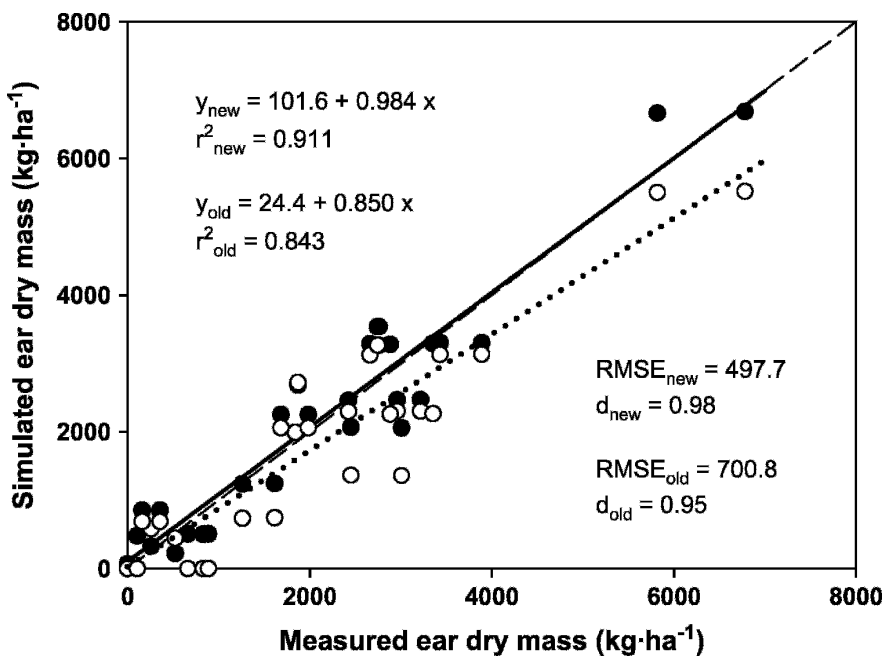

Fig. 7. Model-simulated and field-measured seasonal ear dry weight of sweet corn across treatments in three independent seasons. Simulations were obtained with CERES-Sweet Corn (new, filled symbols) and with CERESMaize, the maize model distributed with DSSAT 4.0 (old, open symbols). Broken line indicates the $\mathrm{y}=\mathrm{x}$ line; continuous line is the regression fitted to simulations of CERES-Sweet Corn $(\mathrm{n}=29, P<0.0001)$; dotted line is the regression fitted to simulations of CERES-Maize $(\mathrm{n}=29, P<0.0001)$. $\mathrm{RMSE}=$ root mean square of the error; $\mathrm{d}=$ Willmott's index of agreement. 


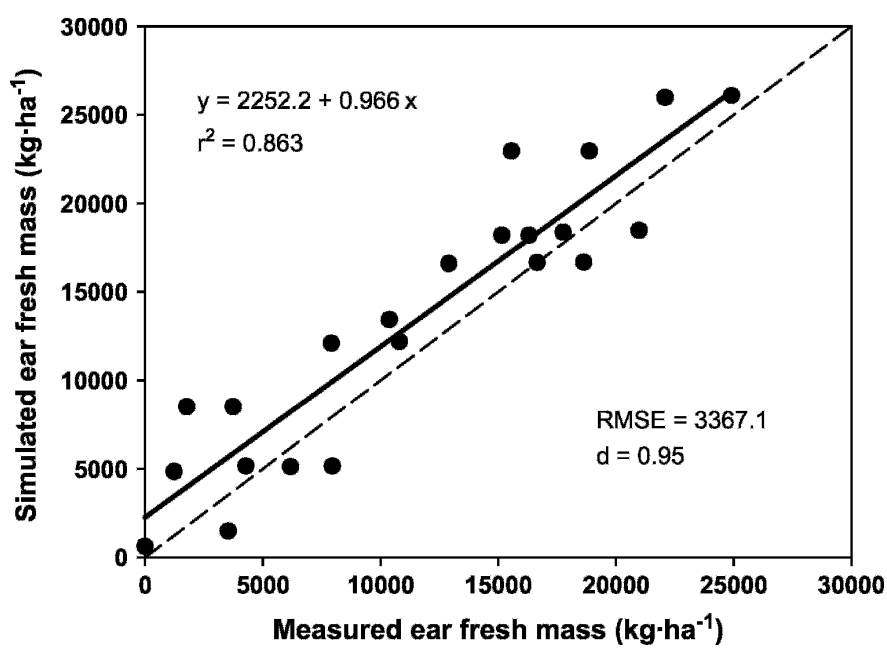

Fig. 8. Model-simulated and field-measured seasonal ear fresh weight of sweet corn across treatments in three independent seasons. Simulations were obtained with CERES-Sweet Corn. Broken line indicates the $\mathrm{y}=\mathrm{x}$ line; continuous line is the regression line $(\mathrm{n}=22 ; P<0.0001)$. $\mathrm{RMSE}=$ root mean square of the error; $\mathrm{d}=$ Willmott's index of agreement.
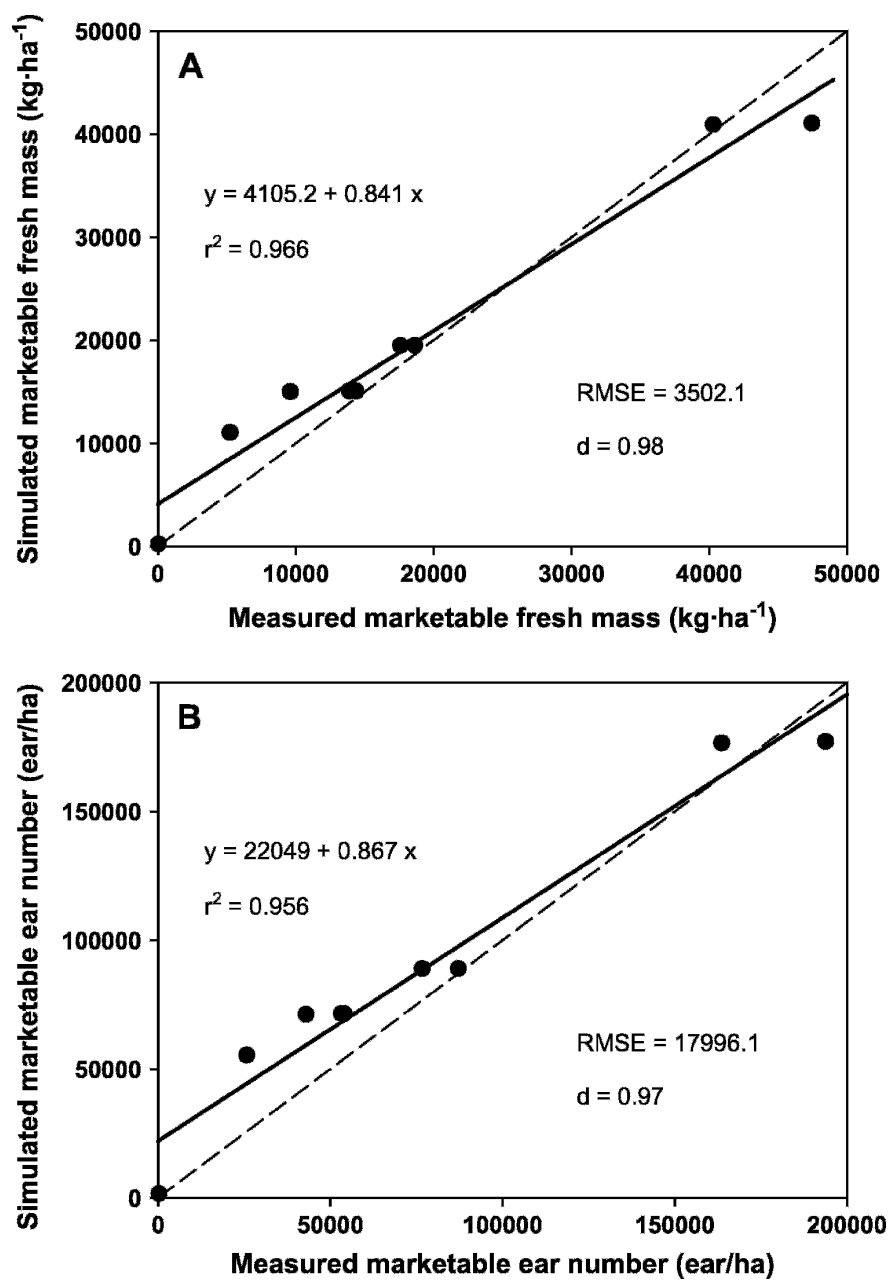

Fig. 9. Model-simulated and field-measured marketable (A) ear fresh weight at harvest and (B) marketable ear number at harvest of sweet corn across treatments in three independent seasons. Simulations were obtained with CERES-Sweet Corn. Broken line indicates the $\mathrm{y}=\mathrm{x}$ line; continuous line is the regression line (in both panels $\mathrm{n}=9 ; P<0.0001$ ). $\mathrm{RMSE}=$ root mean square of the error; $\mathrm{d}=$ Willmott's index of agreement. by DSSAT models. Model simulations of leaf area and shoot biomass (data not shown) were consistently above measured values for this experiment. Excluding the 2005 data from our analysis in Figure 8 reduced the bias of ear fresh weight simulation substantially. The new regression slope would be 0.987 and the intercept would be 942.6 . It is worth noting that excluding these data from the ear dry weight analysis shown in Figure 7 also slightly improved the simulations. The new slope would be 1.01 and the new intercept -95.4 .

EAR QUALITY SIMUlation. Sweet corn ears are marketed according to quality standards. We examined the possibility of incorporating the simulation of ear quality. The U.S. standards for sweet corn fresh market (USDA, 1992) was implemented and tested. Simulations were close to measured values of marketable ear fresh weight yield (Fig. 9A). At low values of marketable yield, when $\mathrm{N}$ application was low, the CERESSweet Corn overestimated marketable fresh weight yields (Eq. 4). Similarly, the model consistently overestimated the number of marketable ears (Fig. 9B), especially at lower yields. Because no water stress was observed, the overpredictions shown in Figure 9 are associated with combined effects of various years and $\mathrm{N}$ doses. Therefore, the simulation of $\mathrm{N}$
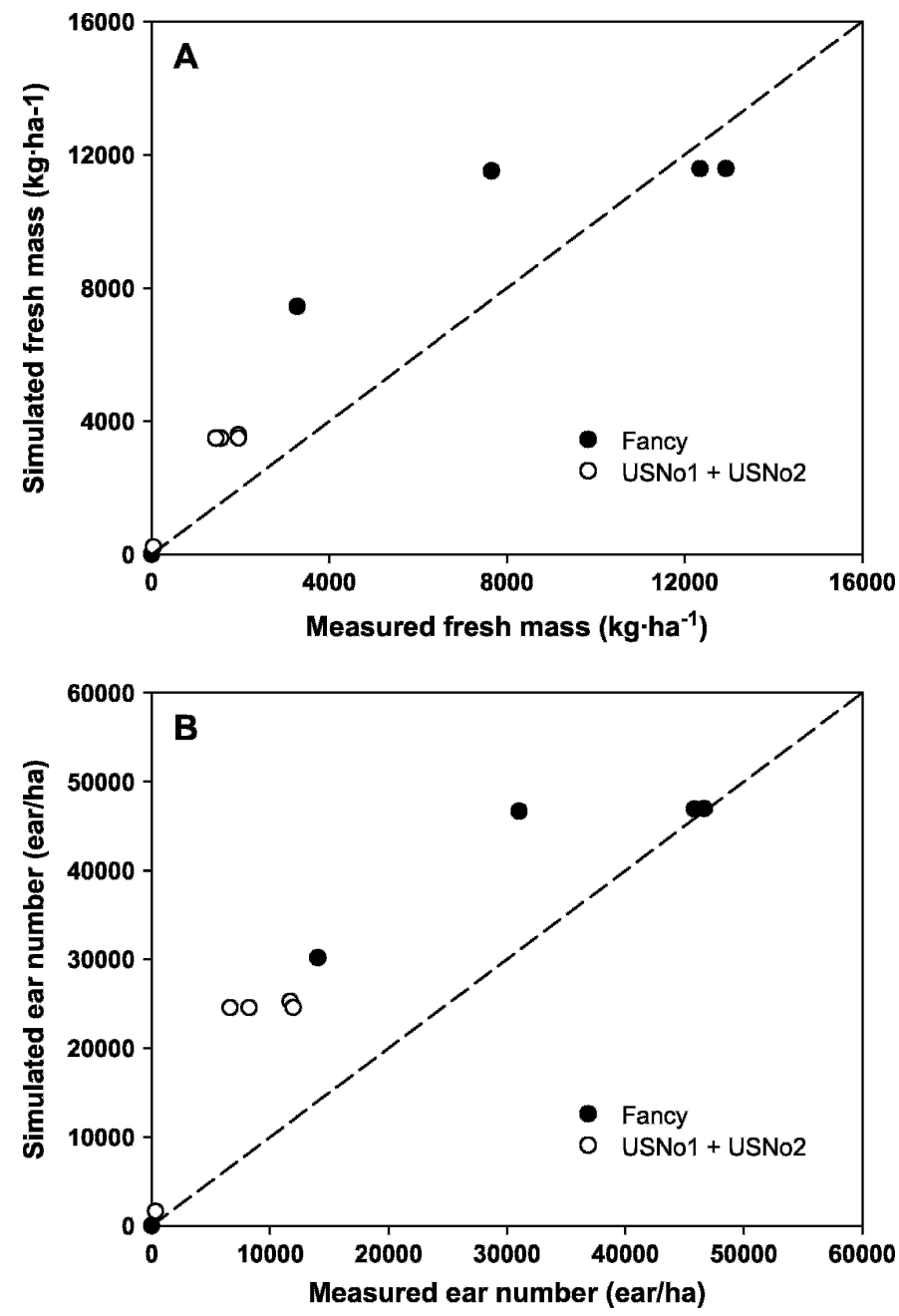

Fig. 10. Model-simulated and field-measured (A) ear fresh weight at harvest and (B) ear number at harvest of Fancy and US No. $1+$ US No. 2 ears of sweet corn across treatments for the 2002 experiment. Simulations were obtained with CERES-Sweet Corn. Broken line indicates the $\mathrm{y}=\mathrm{x}$ line. 
dynamics and the impact of $\mathrm{N}$ levels on ear quality may need further examination.

Data shown in Figure 10 were consistent with this analysis. When $\mathrm{N}$ was less than optimum, there was a general trend to overestimate the fresh weight of Fancy and US No. 1 plus US No. 2 ears as well as ear number. Because ear quality is mostly associated with ear sizes (i.e., kernels/ear), a more mechanistic simulation of ear and kernel set, and the impact of stresses on ear size distribution may be required to adequately simulate ear quality in sweet corn.

Sensitivity analysis. We examined model stability and performance by simulating reduced water and $\mathrm{N}$ supply, and changes in thermal growing conditions and population density. We focused on the new model components. Thus, only the impact on ear dry weight per plant and total marketable ear fresh weight per unit land area is reported. The simulation of limited water and $\mathrm{N}$ supply followed a similar pattern (Fig. 11A, B). However, the model showed more sensitivity to changes in water supply than to changes in N supply. Ear dry weight and marketable yield decreased gradually but almost immediately when the simulated water supply was reduced (Fig. 11A). On the other hand, reducing the amount of fertilizer applied from 200 to $100 \mathrm{~kg} \cdot \mathrm{ha}^{-1} \mathrm{~N}$ resulted in only a $3 \%$ decrease in ear dry weight and marketable yield. Our field measurements indicated that reducing the fertilizer applied from 200 to $133 \mathrm{~kg} \cdot \mathrm{ha}^{-1} \mathrm{~N}$ resulted in $23 \%$ reduction in marketable yield (Cherr et al., 2006). These discrepancies between simulated and measured marketable yields can be associated in part to soil input uncertainties such as initial levels of $\mathrm{NO}_{3}{ }^{-}$and $\mathrm{NH}_{4}{ }^{+}$or too rapid mineralization of soil organic matter, which we have noted previously for this model and site (B.A. Jackson, J.M.S. Scholberg, and K.J. Boote, unpublished data). Hasegawa et al. (2000) reported that CERES models provided just a rough estimate of the $\mathrm{N}$ budget when simulating wheat and maize crops. This lack of model sensitivity under our experimental conditions to simulate yield and yield compo- nents in response to soil $\mathrm{N}$ supply may partially explain the model difficulty to simulate the effects of low and intermediate $\mathrm{N}$ levels on marketable yield (Fig. 9) and especially on ear quality (Fig. 10).

When the thermal environment of the simulations was changed, different responses were observed on ear dry weight and marketable yield (Fig. 11C). The model predicted that in an environment $2.5^{\circ} \mathrm{C}$ warmer, the ear mass would be maintained, whereas the marketable yield would drop by $14 \%$. On the other hand, a $2.5^{\circ} \mathrm{C}$ cooler environment will maintain a similar marketable yield but will reduce the ear mass by $14 \%$. These different responses reflect the different responses to thermal time. Ear growth is a curvilinear function of thermal time (Fig. 1), whereas marketable yield depends on the ear dry weight concentration (Fig. 2), which is a linear function of thermal time.

The simulated responses to changes in plant population density (Fig. 11D) indicated that because more assimilates are available for each plant (i.e., lower population density), the average ear mass per plant increased. This large assimilate pool available for ear growth should trigger prolificacy, but CERES-Maize just simulates a larger single ear rather than considering multiple ears. The marketable yield remained almost unchanged at population densities within the 6 to 9 plants $/ \mathrm{m}^{2}$ range, because larger ears compensated for reduced ear numbers. When population densities increased, both ear mass and marketable yield decreased resulting from simulated barrenness.

\section{Conclusions}

In the present work, we modified the CERES-Maize model distributed with DSSAT 4.0 to simulate sweet corn crops. Our initial interest focused on the simulation of three system components that are critical for sweet corn: ear dry weight, ear fresh weight, and ear quality. Using field-grown commercial super sweet hybrids (sh2) grown in Florida under various $\mathrm{N}$ levels, we developed and tested our model modifications. The original CERESMaize model underpredicted ear growth, especially at high ear dry weight levels. The new daily assimilate ear partitioning rule implemented in the CERES-Sweet Corn model improved simulation of ear dry weight. This model improvement may be readily adapted to the simulation of field corn by CERES-Maize.

The new ear fresh weight component in CERES-Sweet Corn gave adequate performance under commercial population densities. However, we only tested supersweet (sh2) cultivars under adequate water supply. Water stress or different genetic composition (sul, sel genes) may have an impact on the progression of ear dry weight concentration (Fig. 2) and thus may affect the relationship of ear dry weight to ear fresh weight.

Fig. 11. Sensitivity analysis of CERES-Sweet Corn showing simulated ear dry weight [ear DM (grams per plant)] and marketable yield [Mkt Yield (kilogram per hectare)] of sweet corn in response to input changes in (A) water supply, (B) N fertilizer applied, (C) air temperature, and (D) population density. 
Marketable ears are composed of Fancy, US No. 1, and US No. 2 ear classes. Our model development data set showed that variability in Fancy ear size was small. However, observed variability in US No. 1 ear size, and particularly in US No. 2 ear size, was so large that we could not differentiate between the two classes with reasonable certainty. For that reason, we simulated both classes together. Our results indicated the need to further examine the simulation of sweet corn ear number per plant and ear quality. The ability to simulate prolificacy and different ear sizes may be critical for this purpose.

\section{Literature Cited}

Casanova, J.J., T.Y. Lin, and M.Y. Jang. K.C. Tien, J. Judge, O. Lanni, and L.W. Miller. 2005. Field observations during the fourth microwave, water, and energy experiment (MicroWEX-4) 10 Mar.-14 June 2005. Circ. No. 1482. 21 Dec. 2006. <http://edis.ifas.ufl.edu/ AE362>.

Cherr, C.M., J.M.S. Scholberg, and R. McSorley. 2006. Green manure as nitrogen source for sweet corn in a warm temperate environment. Agron. J. 98:1173-1180.

Duncan, W.G. 1975. SIMAIZ, A model for simulating corn growth and yield, p. 32-46. In: D.N. Baker, R.G. Creech, and F.G. Maxwell (eds.). The application of systems methods to crop production. Dept. Agronomy, Mississippi State University, Mississippi State.

Godwin, D.C. and U. Singh. 1998. Nitrogen balance and crop response to nitrogen in upland and lowland cropping systems, p. 55-77. In: G.Y. Tsuji, G. Hoogenboom, and P.H. Thornton (eds.). Understanding options for agricultural production. Kluwer Academic Publishers, Dordrecht, The Netherlands.

Hasegawa, H., D.C. Bryant, and R.F. Denison. 2000. Testing CERES model predictions of crop growth and $\mathrm{N}$ dynamics in cropping systems with leguminous green manures in a Mediterranean climate. Field Crops Res. 67:239-255.

Hoogenboom, G., J.W. Jones, P.W. Wilkens, C.H. Porter, W.D. Batchelor, L.A. Hunt, K.J. Boote, U. Singh, O. Uryasev, W.T.
Bowen, A.J. Gijsman, A. du Toit, J.W. White, and G.Y. Tsuji. 2004. Decision support system for agrotechnology transfer Version 4.0. University of Hawaii, Honolulu.

Jones, C.A. and J.R. Kiniry (eds.). 1986. CERES-Maize: A simulation model of maize growth and development. Texas A\&M Univ. Press, College Station.

Jones, J.W., G. Hoogenboom, C.H. Porter, K.J. Boote, W.D. Batchelor, L.A. Hunt, P.W. Wilkens, U. Singh, A.J. Gijsman, and J.T. Ritchie. 2003. The DSSAT cropping system model. Eur. J. Agron. 18:235265.

Judge, J., J.J. Casanova, T.Y. Lin, K.C. Tien, M. Jang, O. Lanni, and L.W. Miller. 2005. Field observations during the second microwave, water, and energy experiment (MicroWEX-2) 17 Mar.-3 June 2004. Circ. No. 1480. 21 Dec. 2006. <http://edis.ifas.ufl.edu/AE360>.

Otegui, M.E. and R. Bonhomme. 1998. Grain yield components in maize: I. Ear growth and kernel set. Field Crops Res. 56:247256.

Rodov, V., A. Copel, N. Aharoni, Y. Aharoni, A. Wiseblum, B. Horev, and Y. Vinokur. 2000. Nested modified-atmosphere packages maintain quality of trimmed sweet corn during cold storage and the shelf life period. Postharvest Biol. Technol. 18:259-266.

Stapper, M. and G.F. Arkin. 1980. CORNF: A dynamic growth and development model for maize (Zea mays L.). Texas Agr. Expt. Sta., Blackland Res. Center, Temple, Texas.

Tracy, W.F. 2001. Sweet corn, p. 155-197. In: A.R. Hallauer (ed.). Specialty corns. 2nd ed. CRC Press, Boca Raton, Fla.

University of Florida. 2006. Florida automated weather network; report generator. 21 Dec. 2006. <http://fawn.ifas.ufl.edu/scripts/ reportrequest.asp $>$.

U.S. Department of Agriculture (USDA). 1992. United States standards for grades of sweet corn. 21 Dec. 2006. $<$ http://www.ams.usda. gov/standards/cornswt.pdf $>$.

U.S. Department of Agriculture (USDA). 2005. Sweet corn data. 21 Dec. 2006. <http://www.nass.usda.gov:8080/QuickStats/ PullData_US.jsp $>$.

Willmott, C.J. 1982. Some comments on the evaluation of model performance. Bul. Amer. Meteorol. Soc. 63:1309-1313. 